А. Э. Токторов, Ч. С. Эрдолатов. Предупреждение преступности в сфере национальной безопасности стран СНГ

Научная статья

УДК 343.3

DOI 10.18101/2658-4409-2021-3-33-39

\title{
ПРЕДУПРЕЖДЕНИЕ ПРЕСТУПНОСТИ В СФЕРЕ НАЦИОНАЛЬНОЙ БЕЗОПАСНОСТИ СТРАН СНГ
}

(C) Токторов Алтынбек Эгембердиевич

кандидат юридических наук, доцент

vestnik_bsu_uf@mail.ru

(c) Эрдолатов Чыныбек Сайпидинович

кандидат юридических наук, доцент

vestnik_bsu_uf@mail.ru

Ошский государственный юридический институт

Киргизия, 723500, г. Ош, проспект Ленина, 331

Аннотация. В статье рассматриваются актуальные вопросы международного сотрудничества и роль международных организаций в предупреждении преступности в сфере национальной безопасности. Актуальность исследований преступности в сфере национальной безопасности стран СНГ и необходимость разработок мер их предупреждения на сегодняшний день приобретают особую значимость, так как организованная преступность, коррупция, терроризм, экстремизм, наркобизнес, незаконный оборот оружия и связанные с ними криминальные деяния приобретают характер экспансии транснациональной преступности. Проведен криминологический анализ наиболее опасных криминальных деяний, представляющих угрозу национальной безопасности странам СНГ. Акцентировано внимание на причинах и условиях, способствующих преступности в рассматриваемой сфере. В качестве задачи авторы рассматривают и определяют приоритетные направления предупреждения преступности, представляющей криминальную угрозу национальной безопасности, в том числе охватывающие и такие области, как экологическая и информационная безопасность. Уделено внимание вопросам роли международных организаций в предупреждении преступности в сфере национальной безопасности.

Ключевые слова: транснациональная организованная преступность, интерпол, оперативно-разыскная информация, киберпространство и киберпреступность.

\section{Для цитирования}

Токторов А. Э., Эрдолатов Ч. С. Предупреждение преступности в сфере национальной безопасности стран СНГ // Вестник Бурятского государственного университета. Юриспруденция. 2021. Вып. 3. С. 33-39.

Предупреждение преступности - достаточно сложный и многоаспектный процесс, образующий комплекс разнообразных мер, в реализацию которых вовлечены государственные органы, общественные организации и другие субъекты, деятельность которых направлена на противодействие процессам детерминации преступности. 
Как верно отмечает А. Х. Миндагулов, профилактика преступлений представляет собой специфическую область регулирования общественных отношений с позиции поиска и обнаружения комплекса причин и условий преступности, а также выработки мер по их устранению, которая, по сути, носит управленческий характер. Несомненно, особенности управления в сфере предупреждения и профилактики преступлений находятся прежде всего в зависимости от специфики субъекта, объектов воздействия, форм и методов профилактической деятельности $[1$, c. 7$]$.

Как правило, преимущественная часть криминологов подразделяет предупредительную деятельность на два его уровня: общесоциальное предупреждение и специальное предупреждение. Следует отметить, что практически всеми ученымикриминологами признается, что по содержанию предупредительные меры могут быть социальными, экономическими, политическими, правовыми, организационно-управленческими, культурно-воспитательными.

Как свидетельствует контент-анализ литературы, преимущественной частью авторов в сфере предупреждения преступлений выделяются следующие основные функции государственных органов: а) определение цели и исходящих из нее задач предупреждения преступных посягательств, а также основных приоритетных направлений предупредительной деятельности, с учетом криминологической ситуации, складывающейся на данный период времени; б) планирование намеченной предупредительной деятельности; в) разработка и принятие с учетом современных реалий государственной комплексной Программы борьбы с преступностью либо по ее отдельному направлению; г) определение и координация предупредительной деятельности субъектов, на которых возложено исполнение таких функций; д) осуществление контрольных функций за деятельностью субъектов, осуществляющих предупредительную деятельность; е) организация и осуществление обмена опытом в рамках международного сотрудничества; и) решение вопросов связанных с кадровым и материально-финансовым обеспечением рассматриваемой деятельности.

Обоснована позиция К. А. Исаевой и А. А. Салиева, что «...в странах СНГ (после распада СССР) требовалось проведение коренных преобразований на основе детально выработанной стратегии и тактики в контексте моделей реформирования экономики зарубежных стран, а также специфики реальной действительности каждого отдельно взятого государства, в том числе менталитета страны. Сложившаяся ситуация в данной сфере не только привела к существенным дефектам и просчетам в области экономики, но и стала значительным криминогенным потенциалом для появления организованной преступности более широкой направленности» [2].

Все это влияет на национальную безопасность государства, причем, ни у кого не вызывает сомнений, что содержание организованной преступности в большей степени на сегодняшний день имеет экономический аспект, поскольку главным ее источником получения прибыли является экономика.

Ситуацию ухудшает и то, что в процессе эволюционного развития организованной преступности наблюдаются такие изменения, как ухудшение практически всех криминологических показателей и рост криминальной активности 
А. Э. Токторов, Ч. С. Эрдолатов. Предупреждение преступности в сфере национальной безопасности стран СНГ

и трансформация его в транснациональную организованную преступность [3]. Поэтому является логичным криминологическую безопасность рассматривать не только внутри страны, но и в рамках СНГ.

Вопросы объединения усилий стран СНГ по предупреждению транснациональной преступности стали актуальными после распада советских государств, поскольку сохранилось единое криминальное пространство и тесная связь организованной преступности данных государств.

Следует отметить, что основными направлениями сотрудничества в целом в рассматриваемой нами сфере являются то, что заложено в Конвенции о правовой помощи и правовых отношениях по гражданским, семейным и уголовным делам (Кишинев, 7 октября 2002 г.), где в статье 6 определен объем правовой помощи:

- выполнение процессуальных и иных действий, предусмотренных соответствующим законодательством запрашиваемой Договаривающейся Стороны, в частности, составления, пересылки и вручения адресату документов, производства осмотров, обысков, выемок, передачи вещественных доказательств, проведения экспертиз, допроса сторон, третьих лиц, подозреваемых, обвиняемых, потерпевших, свидетелей, законных представителей обвиняемых, экспертов;

- предъявления лица для опознания, включая и использование видеосвязи, видеозаписи и иных технических средств, розыска запрашиваемых лиц;

- осуществления необходимых оперативно-разыскных мероприятий по запросу одной из сторон в рамках уголовного преследования, выдачи лиц для привлечения их к уголовной ответственности или приведения приговора в исполнение, за совершенное преступление;

- розыска и ареста (изъятия) финансовых средств и имущества, полученных криминальным путем, а также доходов от такой деятельности, розыска имущества и денежных средств гражданских ответчиков для исполнения решений по таким делам [4].

Кроме того, Н. Н. Сулайманова в своей работе обоснованно указывает, что «...общие меры по предупреждению коррупционных преступлений представляют собой комплекс мер, направленных на повышение уровня жизни населения; укрепление и развитие экономики страны; развитие сильного гражданского общества; формирование идеологии и закрепление нравственных, культурных ценностей; политические преобразования, способствующие поддержанию условий для развития демократического государства (реформа судебной системы, правоохранительных органов); укрепление всех ветвей государственной власти; совершенствование законодательства и т. д.» [5, с. 41].

Исходя из вышеизложенного в рамках противодействия, в том числе предупреждения транснациональной преступности, представляющего национальную безопасность, на наш взгляд, необходимо выделить следующие направления: 1) системный подход к формированию государственной и межгосударственной стратегии борьбы с преступлениями, представляющими угрозу безопасности государств, а в необходимых случаях и по отдельным взаимосвязанным сферам транснациональной преступности; 2) активная разработка заинтересованными сторонами в рамках сотрудничества СНГ основополагающих нормативных правовых документов по противодействию, включая и предупреждение совершения 
нетрадиционных форм преступлений в сфере безопасности; 3) совместное планирование и осуществление намеченных мероприятий, в том числе и проведение «контролируемых поставок» в сфере незаконного оборота оружия, наркотических средств и т. п.; 4) выработка единообразных согласованных подходов к определению критериев при криминализации противоправных деяний транснациональными преступными формированиями на территории государств — участников СНГ; 5) действенная координация и принятие мер для осуществления слаженной работы под руководством единого управляющего центра; 6) дальнейшее развитие сотрудничества в целях обмена между странами СНГ информацией в оперативно-разыскной, криминалистической, справочной и иных сферах, представляющее взаимный интерес для расследования и раскрытия криминальных деяний, угрожающих безопасности государств; 7) систематический обмен опытом по расследованию преступлений в сфере национальной безопасности, носящий транснациональный характер, а также организация обучения специалистов в рамках ОДКБ; 8) разработка и обмен методическими рекомендациями, нормативными правовыми актами, а также проведение совместных научных изысканий по наиболее актуальным вопросам противодействия, в том числе предупреждение преступлений в сфере безопасности государств; 9) создание соответствующих условий для обеспечения участия представителей сторон при оказании правовой помощи в производстве расследования уголовного дела; 10) меры для организации эффективного сотрудничества по противодействию коррупции, в том числе путем заключения соглашения в рамках СНГ в данной сфере; 11) разработка системы оказания правовой помощи в розыске денежных средств и имущества за рубежом, нажитых в результате криминальных деяний; 12) активизация сотрудничества правоохранительных органов СНГ по выявлению и пресечению деятельности, представляющей угрозу национальной безопасности государств и исходящей от внешних деструктивных сил, которые действуют под прикрытием некоторых правозащитных организаций, благотворительных фондов, религиозных и общественных организаций; 13) создание единой межгосударственной системы контроля, т. е. полноценного банка данных по вопросам, связанным с противодействием транснациональной преступности, угрожающей всем видам безопасности, с целью повышения эффективности предупреждения и пресечения криминальной деятельности организованной преступностью. Такая информационно-поисковая система должна содержать полные сведения для расследования преступлений не только на национальном уровне, но и межгосударственном и при этом необходим сбор информации не только о лидерах и членах преступных группировок, но и о лицах, сопричастных к организованной преступности; 14) совершенствование воспитательной работы населения в духе национальной и религиозной терпимости и неприятия идеологии религиозно-политического экстремизма. В этих целях необходимы образовательные программы, которые будут направлены на формирование у детей и молодежи толерантного сознания, межкультурному диалогу; проведение социально- психологических экспертиз теле- и радиопрограмм, публикаций в СМИ; разработка методов диагностики и мониторинга проявлений экстремистских настроений в обществе; 15) сложность феномена транснациональной 
А. Э. Токторов, Ч. С. Эрдолатов. Предупреждение преступности в сфере национальной безопасности стран СНГ

преступности, представляющей угрозу национальной безопасности государств, его уровень непредсказуемости и комплексный характер требуют разработки иных прогностических методов исследования, оценки состояния с учетом целого ряда факторов, влияющих на интеграцию данных опасных проявлений в международное пространство.

Как показывает контент-анализ различных источников, специалистами преимущественно выделяется три основных стратегических подхода к нейтрализации неблагоприятных последствий: a) адаптивный, предполагающий проведение работ, связанный с усилением приспосабливаемости к неблагоприятным условиям экосистем; б) оборонительный — направлен на повышение эффективности защиты экологической безопасности за счет принятия мер по снижению уязвимости экосистем государства; в) корпоративный - включает в себя деятельность, связанную с организацией международного сотрудничества по устранению причин опасных последствий. Для реализации указанных подходов считаем обоснованным, что должны быть приняты следующие основные меры:

1) проведение профессиональной правовой экспертизы действующего природоохранного законодательства и иных нормативных правовых актов, регулирующих общественные отношения в сфере экологии и охраны окружающей среды. На основе такого анализа, во-первых следует разработать и принять экологическую доктрину, где необходимо отразить совокупность официальных взглядов на приоритетную цель, задачи, требующие своего разрешения, основополагающие принципы и направления экологической безопасности. Такая доктрина станет отправной позицией для принятия ряда важных законодательных актов в сфере обеспечения экологической безопасности государства; во-вторых, выявленные в ходе правовой экспертизы противоречия либо проблемные аспекты, препятствующие реализации норм, станут основанием для выработки предложений по внесению изменений либо дополнений в соответствующие статьи природоохранного законодательства и иные нормативные правовые акты государства; в-третьих, выработать эффективную систему мониторинга для контроля за выполнением на должном уровне нормативных правовых актов со стороны соответствующих органов, на которых возложена ответственность за выполнение намеченных мероприятий и принятие решений в рассматриваемой сфере;

2) экологические проблемы должны разрешаться с учетом существующей экологической угрозы на межгосударственном уровне, при этом немаловажное значение должно отводиться принятию мер по нейтрализации коррупционных проявлений, поскольку в настоящее время ряд экологических преступлений носит транснациональный характер.

Таким образом, можно сделать следующие выводы:

1. Чтобы обеспечить национальную безопасность государства в целом, важно учитывать ее геополитическую позицию, глобальную и внутреннюю ситуацию, которые требуют значительного внимания.

Ситуацию в государстве усложняет тот факт, что многие опасные преступные группы, представляющие угрозу национальной безопасности, поддерживают тенденцию к дальнейшему расширению влияния, что подтверждает их 
криминологические характеристики. Эта ситуация в странах СНГ требует системных мер по предотвращению негативных явлений, которые предлагаются в настоящей работе.

2. Для обеспечения экологической безопасности необходимо принимать уголовно-правовые меры, а также нужен комплексный подход государственных органов и общественных организаций, деятельность которых направлена на сокращение уровня негативных антропогенных факторов, влияющих на окружающую среду и на население страны. Рациональное использование и восстановление природных ресурсов, создание и поддержание здоровой экологической среды все это должно быть одним из целей социально-экономического развития в стране. Актуальная задача - экологизация законодательства, направленного на предупреждение экологических угроз и рисков, и регулирование общественных отношений для создания экосистемного подхода.

3. Следующим важным компонентом национальной безопасности является информационные составляющие. Поскольку разработка и внедрение новых информационных технологий приносят обществу не только положительные результаты, но и значительные угрозы национальной безопасности и информационному обеспечению государственной политики страны, то эта сфера определенно требует разработки эффективной системы противодействия угрозам, посягающим на конституционные права и свободы человека в сфере информационной деятельности, наносящим вред индивидуальному и общественному сознанию в области духовной жизни личности.

\section{Литература}

1. Миндагулов А. Х. Научные основы управления в сфере профилактики преступлений : диссертация на соискание ученой степени доктора юридических наук: 12.00.08. Москва, 1990. 476 с. Текст : непосредственный.

2. Исаева К. А., Салиев А. А К вопросу об основных факторах, детерминирующих торговлю людьми, с участием организованных преступных групп // Международный журнал. URL: //https://elibrary.ru wnload/elibrary_ 29712678_58339517.pdf. Текст : электронный.

3. Каминский А. М. Методологические и теоретические основания построения криминалистической модели организации преступной деятельности в системе организованного преступного сообщества // «Черные дыры» в российском законодательстве : юридический журнал. Москва, 2008. № 2. С. 255-257. Текст : непосредственный.

4. Конвенция о правовой помощи и правовых отношениях по гражданским, семейным и уголовным делам (Кишинев, 7 октября 2002 г.). URL ://https://online. zakon.kz/document /?doc_id=1034672. Текст : электронный.

5. Сулайманова Н. борьбы с должностными преступлениями: на материалах Кыргызской Республики : автореферат диссертации на соискание ученой степени доктора юридических наук: 12.00.08. Бишкек, 2012. 49 с. Текст : непосредственный.

Статья поступила в редакичю 08.09.2021; одобрена после рецензирования 13.10.2021; принята к публикации 08.11.2021. 
А. Э. Токторов, Ч. С. Эрдолатов. Предупреждение преступности в сфере национальной безопасности стран СНГ

\section{CRIME PREVENTION IN THE NATIONAL SECURITY OF CIS COUNTRIES}

Altynbek E. Toktorov

Cand. Sci. (Law), A/Prof.

vestnik_bsu_uf@mail.ru

Chynybek S. Erdolatov

Cand. Sci. (Law), A/Prof.

vestnik_bsu_uf@mail.ru

Osh State Law Institute

331 Lenina Prospect, Osh 723500, Kyrgyzstan

Abstract. The article discusses the topical issues of international cooperation and the role of international organizations in the prevention of crime against national security. The research on crime against national security of CIS countries and development of measures to prevent them today are of particular importance, since the organized crime, corruption, terrorism, extremism, drug and arms trafficking and related criminal acts acquire the character of an expansion of transnational crime. We carried out a criminological analysis of the most dangerous criminal acts posing a threat to the national security of CIS countries. Our attention was focused on the reasons and conditions, which are conducive to crimes under consideration. We determined the priority areas for the prevention of national security threats, including those concerning environmental and information security, and paid much attention to the role of international organizations in prevention of crime against national security.

Keywords: transnational organized crime, interpol, criminal intelligence information, cyberspace and cybercrime.

\section{For citation}

Toktorov A. E., Erdolatov Ch. S. Crime Prevention in the National Security of CIS Countries. Bulletin of Buryat State University. Law. 2021; 3: 33-39 (In Russ.).

The article was submitted 08.09.2021; approved after reviewing 13.10.2021; accepted for publication 08.11.2021. 